\title{
Comparasion Unjuk Kerja Mesin Bensin dengan Bahan Bakar Premium dan Bioethanol [E-15]
}

\author{
Bambang Junipitoyo ${ }^{1}$ \\ 1)Politeknik Penerbangan Surabaya \\ Jl. Jemur Andayani I, No. 73 Surabaya 60236 \\ Email : ararya.pendopo@gmail.com
}

\begin{abstract}
ABSTRAK
Bio-Ethanol merupakan bahan bakar yang menghasilkan polutan yang rendah, Bioethanol merupakan bahan bakar yang aman digunakan sebagai bahan bakar, titik nyala etanol tiga kali lebih tinggi dibandingkan bensin, Emisi hidokarbon lebih sedikit. Bioethanol E-15 merupakan campuran premium 85\% - Bioethanol 15\%. Kinerja mesin tertinggi diperoleh pada campuran premium 85\%-bioethanol 15\% [E-15] dengan peningkatan torsi, daya output $10,15 \%$, dan konsumsi bahan bakar spesifik meningkat 2,22\%.

Penelitian ini dilakukan pada mesin Bensin dengan sistem pemasukan bahan bakar port injection dengan variable speed antara 1000-5000 rpm dengan interval $500 \mathrm{rpm}$, dimana Campuran Bioethanol-Premium [E15] dimasukkan ke dalam ruang bakar melalui injector. Tujuan penelitian ini adalah untuk mengetahui unjuk kerja mesin bensin dengan bahan bakar bensin dan E-15.

Hasil yang diharapkan mendapatkan nilai pengaturan rasio kompresi dan waktu pengapian yang maksimal serta nilai unjuk kerja yang dinyatakan dalam: daya, torsi, efisiensi thermal, sfc.
\end{abstract}

Kata kunci: Bioethanol, Premium, Mesin Bensin.

\section{PENDAHULUAN}

Kebutuhan akan energi yang terus meningkat, namun ketersediaan sumber daya alam yang terbatas. Kebutuhan energi yang tidak terpenuhi pada sektor industri dan perekonomian merupakan suatu keniscayaan jika hanya mengandalkan sumber daya alam yang tidak dapat diperbaharui seperti minyak bumi, batu bara dan gas alam. Selain itu penggunaan sumber daya alam tersebut diatas juga mempengarui lingkungan ${ }^{[1]}$. Seiring pertumbuhan kendaraan Indonesia sebagai alat transportasi semakin meningkat, maka kebutuhan bahan bakar semakin bertambah sehingga persediaan bahan bakar minyak terus berkurang. Disamping itu dampak dengan bertambahnya kendaraan bermotor maka kandungan emisi gas buang $\left(\mathrm{CO}, \mathrm{CO}_{2}\right.$ dan $\left.\mathrm{HC}\right)$ kendaraan bermotor dengan bahan bakar premium makin tinggi. Oleh Sebab dibutuhkan Energi alternatif sebagai upaya untuk mengurangi pencemaran udara yang berbahaya dari kendaraan bermotor.

Salah satu energi alternatif yang saat ini berkembang adalah penggunaan bioethanol. Bioethanol adalah bahan bakar yang ramah lingkungan dan merupakan salah satu bentuk energi terbaharui yang dapat diproduksi dari tumbuhan. Bioetanol dapat dibuat dari tanamantanaman yang umum, misalnya tebu, kentang, ubi kayu, ubi jalar, sagu dan jagung. Ubi kayu, ubi jalar, dan jagung merupakan tanaman pangan yang biasa ditanam rakyat hampir di seluruh wilayah Indonesia, sehingga jenis tanaman tersebut merupakan tanaman yang potensial untuk dipertimbangkan sebagai sumber bahan baku pembuatan bio-ethanol atau gasohol.

Bioethanol ini dapat digunakan sebagai bahan bakar pada kendaraan bermotor seperti mobil,sepeda motor, traktor dll. Sebagai campuran premium pada motor bensin, bioethanol adalah sumber energi yang dapat diperbarui. Bioethanol diperoleh dengan cara fermentasi glukosa yang diperoleh dari tanaman yang mengandung karbohidrat ${ }^{[2]}$. 
Nilai oktan bioetanol lebih tinggi dibandingkan dengan premium. Walaupun ethanol/bio-ethanol mempunyai nilai oktan (octane rating ) lebih tinggi dan emisi yang lebih bersih dibanding premium, namun ethanol/bio-ethanol juga mempunyai sifat korosif dan membuat mesin lebih sulit distarter. Sifat korosif ini menyebabkan diperlukannya material yang tahan korosif pada peralatan-peralatan tertentu seperti, tanki bahan bakar, karburator, pipa-pipa, karet-karet penyekat dan lain-lain peralatan.

Beberapa keuntungan dari pemanfaatan Bioethanol sebagai bahan bakar pada motor bakar diantaranya, Bioetanol merupakan bahan bakar yang aman digunakan sebagai bahan bakar, titik nyala etanol tiga kali lebih tinggi dibandingkan bensin, Emisi hidokarbon lebih sedikit. Kekurangan bioethanol yakni Mesin dingin lebih sulit melakukan starter, Bioetanol bereaksi dengan logam seperti magnesium dan aluminium.

Penggunaan Bio-ethanol sebagai pengganti atau substitusi Premium telah dilaksanakan di berbagai negara, seperti Amerika Serikat, Jerman, Belanda, Uni Eropa, New Zaeland, Brazilia serta banyak negara lain, tetapi hanya Uni Eropa dan Amerika Serikat yang telah menerapkan teknologi mesin kendaraan untuk ethanol $85 \%$ (E85) secara komersial ${ }^{[3]}$.

Bioethanol juga dapat sebagai campuran bahan bakar bensin. Hal ini telah dilakukan pada beberapa penelitian sebelumnya: Yousufuddin syed (2007); melakukan penelitian dengan ethanol-bensin tanpa timbal (E0, E10, E25, E35, E65),Variable rasio kompressi (9:1 dan 11:1), Rasio udara-bahan bakar. Pikunas. A (2003) melakukan penyelidikan tentang campuran bahan bakar 10\% ethanol-bensin. Setiyawan (2007); meneliti campuran ethanol $85 \%$ dan premium $15 \%$ (E85\%) dengan ignition timing dan compression ratio. Radu. A (2014) : melaksanakan penelitian campuran ethanol-bensin : E20 dan E85 pada putaran 3000 rpm. Kumbhar.V.S (2012); Effect of lower Ethanol gasoline blends on performance and emission characteristics of the single cylinder SI Engine. Ozcelik. A.E (2013); An Study on the effects of bioethanol-unleaded gasoline blends on engine performance in a spark ignition engine. Saridemir. S (2012);

Tujuan dari penelitian ini adalah untuk mengetahui perbandingan unjuk kerja mesin bensin dengan bahan bakar bensin dan E-15. Mesin ini adalah dilengkapi dengan unit kontrol elektronik diprogram yang memiliki fasilitas untuk menyesuaikan kesesuaian injeksi dan pengapian timing. Fungsi ECU adalah untuk mengontrol jumlah bahan bakar, timing injeksi, timing pengapian dan putaran mesin dengan menerima sinyal dari enam sensor. Sensor ini adalah oksigen sensor, sensor berjenis tekanan udara, intake sensor suhu udara, sensor posisi throttle, didinginkan sensor suhu air dan sensor kecepatan mesin. Sebuah sistem injeksi bahan bakar multi port dengan yang digunakan untuk menyuntikkan bahan bakar ke daerah katup intake port ke ruang bakar. Sistem pengapian adalah dirancang distributor semi-statis dengan kurang pengapian. 


\section{METODOLOGI}

Dalam studi ini, percobaan dilakukan oleh Sinjai mesin $20 \mathrm{~kW}$, dua silinder, dan pengapian busi. Mesin spesifikasi diberikan dalam Tabel 1.

\begin{tabular}{|l|l|}
\multicolumn{2}{c}{ Table 1. SINJAI engine specification } \\
\hline Engine type & SINJAI 20 \\
\hline Number of cylinder & 2 \\
\hline Bore x stroke & $76 \times 71 \mathrm{~mm}$ \\
\hline Displacement volume & $650 \mathrm{cc}$ \\
\hline Compression ratio & 9 \\
\hline Control system & Programmable ECU \\
\hline Fuel intake system & multi port injection \\
\hline Maximum torque & $57 \mathrm{Nm} / 3000 \mathrm{rpm}$ \\
\hline Maximum Power & $20 \mathrm{~kW} / 4500 \mathrm{rpm}$ \\
\hline Coolant system & liquid with Radiator \\
\hline
\end{tabular}

Waterbrake dinamometer dengan kapasitas daya $120 \mathrm{hp}$ yang digunakan dalam percobaan ini. bahan bakar konsumsi diukur dengan konsumsi bahan bakar waktu per $25 \mathrm{cc}$ bahan bakar dalam gelas ukur, sedangkan konsumsi udara pembakaran diukur menggunakan meteran aliran udara. emisi parameter, suhu gas buang dan rasio bahan bakar udara yang diukur dengan menggunakan STARGAS gas buang analyzer. Gelas ukur bahan bakar dipasang ke mesin bensin dan ini terkandung bahan bakar bioetanol bensin dicampur bergantian (E0, E5, E10, E15 dan E20). Diagram skematik setup eksperimental ditunjukkan pada Gambar. 1.

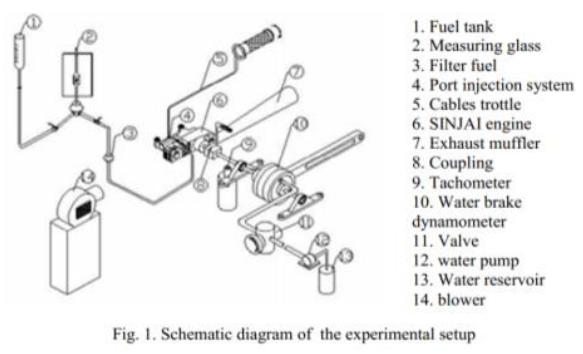

Kinerja dan emisi dari mesin berjalan pada bahna bakar bensin dan E-15.

\section{HASIL PENELITIAN}

Unjuk kerja mesin tidak sama untuk setiap putaran mesin sehingga perlu untuk mengetahui kinerja karakteristik mesin untuk setiap putaran mesin. Dengan adanya penambahan bioetanol akan mempengaruhi unjuk kerja mesin. Parameter kinerja mesin meliputi torsi, daya, rata-rata tekanan efektif, konsumsi bahan bakar spesifik dan efisiensi termal.

Torsi adalah ukuran dari kemampuan untuk memproduksi mesin bekerja dan digunakan untuk mengatasi rintangan di jalan atau untuk meningkatkan kecepatan mesin. Gambar . 1.1 menunjukkan pengaruh bioetanol - bensin campuran bahan bakar yang berbeda pada output torsi. Output tertinggi torsi $54.66 \mathrm{Nm}$ terjadi pada putaran mesin $3000 \mathrm{rpm}$ dengan bahan bakar E15. Dengan bahan bakar E-15 dapat meningkatkan output torsi 10,15 $\%$ dibandingkan dengan menggunakan bensin. Kenaikan ini disebabkan bahwa penambahan bioetanol benar untuk menghasilkan campuran kimia yang tepat sehingga menjadi sempurna atomisasi dan pembakaran proses. Hal ini dapat dibuktikan bahwa emisi HC dari E15 bahan bakar dicampur lebih rendah . 


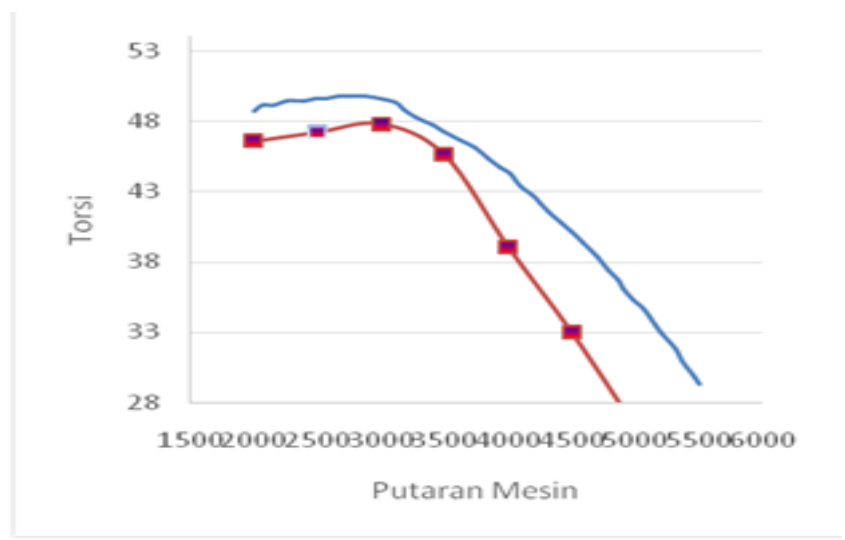

Gambar 1. Grafik Torsi - Putaran Mesin

Jumlah daya rem sebanding dengan output torsi yang terjadi , karena terkait dengan beban pengereman dengan waterbrake dinamometer. Beban pengereman peningkatan torsi lebih besar terjadi. Secara teoritis, ketika kecepatan mesin meningkat, output daya juga akan meningkat . Gambar . 1.2 Grafik perbandingan Daya terhadap Putaran Mesin. Output daya tertinggi 18,25 watt terjadi pada putaran mesin $3.500 \mathrm{rpm}$ dan diproduksi oleh bahan bakar E15 dicampur. Secara keseluruhan, penambahan $15 \%$ bioethanol bahan bakar bensin dapat meningkatkan output daya 10,15\% dibandingkan dengan menggunakan bensin murni .

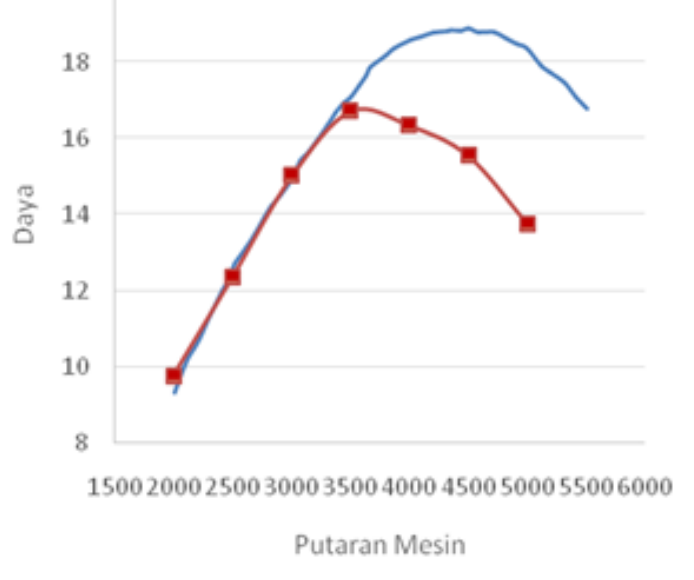

Gambar 2. Grafik perbandingan Daya terhadap Putaran Mesin

Hubungan antara putaran mesin dan konsumsi bahan bakar untuk campuran bahan bakar yang berbeda (bioetanol dan bensin) ditunjukkan pada Gambar. 1.3. Hal ini ditunjukkan dalam gambar ini, bsfc menurun sebagai bioetanol persentase meningkat. Sebagai kecepatan mesin meningkat mencapai $3500 \mathrm{rpm}$, bsfc menurun mencapai nilai minimum. Hal ini disebabkan oleh peningkatan efisiensi termal rem. Gambar. 1.3 menunjukkan pengaruh yang berbeda-bioetanol bensin dicampur bahan bakar rem konsumsi bahan bakar spesifik. Gambar. menunjukkan bahwa dengan penambahan persentase bioethanol akan menghasilkan sfc lebih tinggi dibandingkan dengan bensin murni sampai $2,22 \%$. Hal ini disebabkan nilai kalori yang lebih rendah dibandingkan dengan bioetanol bensin, sehingga untuk menghasilkan kekuatan yang sama untuk waktu tertentu akan memerlukan konsumsi bahan bakar yang lebih besar. Untuk menggunakan bensin murni, sfc minimum adalah $0,17 \mathrm{~kg} / \mathrm{KW}$.jam pada 3500 putaran mesin rpm. 


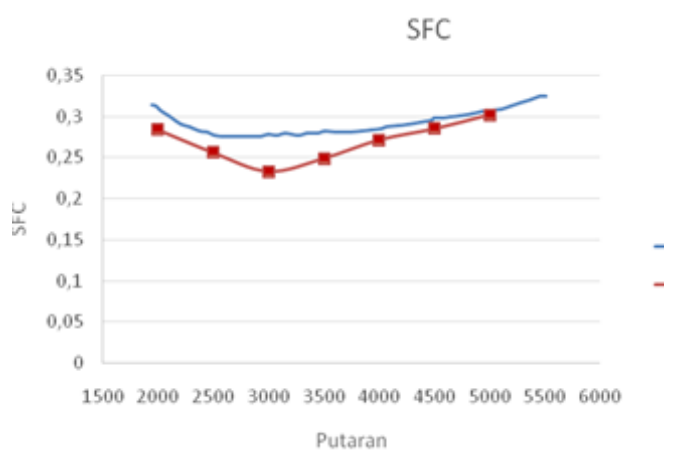

Gambar 3. Grafik perbandingan SFC terhadap Putaran Mesin

\section{KESIMPULAN}

Dari serangkaian pengujian, perhitungan, dan analisis data yang telah dilakukan, maka dapat disimpulkan sebagai berikut:

Unjuk kerja mesin yang optimum diperoleh pada campuran bioethanol $15 \%$ dengan peningkatan torsi, daya output $10,15 \%$, dan konsumsi bahan bakar spesifik meningkat 2,22\%

\section{DAFTAR PUSTAKA}

Misri Gozan. (2008), "Bioethanol berbahan bagas untuk energy alternative". Bahan bakar nabati yang cinta bumi, Est 1849. pp. 1-2.

Supriyono. A. (2008), "Pengembangan Bahan Bakar Nabati untuk mengurangi Dampak Pemanasan Global”. Seminar Nasional kebijakan pemanfaatan lahan dalam menanggulangi dampak pemanasan global. pp. 1-11.

"Fuel Quality Monitoring “.Langit Biru, Kementerian Lingkungan Hidup, (2007), pp $(16,17,25)$

N. Jeuland, N, Montagne \& X. Gautrot. (2004), "Potentiality of Ethanol as a Fuel for Dedicated Engine”. Oil \& Gas Science and Technology - Rev. IFP, , Institut Frances du Petrole, Vol. 59 No.6, pp. 559-570

B.M. Masun, H.H. Masjuki, M.A. Kalam, \& I.M. Rizwanul Fattah. (2013) "Effect of ethanol-gasoline blend on Nox emission in SI Engine". Renewable and Suitable Energy Review 24, Elsevier, pp 209-222.

Jahirul. M.I, Masjuki, H.H., Saidur, R., Jayed, M.H., dan Wazed, M.A., (2010). "Comparative engine performance and emission analysis of CNG and gasoline in a retrofitted car engine". Applied Thermal Engineering. (2010) hal 2219-2226.

Kalam, M.A., Masjuki H. H., (2011), "An experimental investigation of high performance natural gas engine with direct injection", Kuala Lumpur, Malaysia: Department of Mechanical Engineering, University of Malaysia.

Pulkrabek, Willard W (1997), Internal Combustion Engine, Prentice Hall, New Jersey. 